\title{
Smart Home for Elderly: Exploring Gap between Existing Home Communication System and Needs of Elderly
}

\author{
R. Unesha Fareq ${ }^{*}$ and T. Neeraja \\ Department of Family Resource Management, APGC, Acharya N.G. Ranga Agricultural \\ University, Lam-522034, Guntur, Andhra Pradesh, India \\ *Corresponding author
}

\section{A B S T R A C T}

\begin{tabular}{|l|}
\hline Ke y w o r d s \\
Home communication \\
system, Ageing in \\
place, Elderly people, \\
Existing home \\
communication \\
systems, Needs of \\
elderly, Standard \\
guidelines of home \\
communication \\
system
\end{tabular}

Ageing in place can be defined as the tendency of elderly people to live independently in their own house. The desires to live independently during old age throw challenge to interior designers to think up suitable dwelling that facilitate elderly to age in place. The present research aimed at identifying the gap between existing home communication system and housing needs of elderly. The elderly women in the age of sixty and above who were able to carry out their daily chores were selected as sample. The sample was drawn from Kurnool district of Andhra Pradesh. The standard design guidelines evolved through research by various Government and Non-government organizations and researchers served as a yardstick to identify the existing features and needs of elderly people. The results revealed that families with high monthly income and who are living in relatively big houses were found with advanced home communication system. The elderly felt essential to provide a house with all the required home communication system which are elderly friendly and easy to operate. The highly significant chi-square value revealed a strong evidence against the null hypothesis. Hence there exists an association between the existing home communication system and the needs of the respondents to age in place. Home communication devices were not popular among existing houses under the study.

\section{Introduction}

The term Home communication systems refers to the devices that allow the people to communicate using audio visual aids from various spaces in the home without direct interaction. These devices are going to be very familiar technology that will be adopted in the near future while designing both residential and commercial interiors to ensure comfortability and safety. Ageing population and advancement of modern smart technologies are mutually playing a crucial role in both developing and developed countries for providing services to the elderly people to age in place (Bostjan, 2018). Smart homes with required communication systems and healthcare facilities can allow the elderly 
people to stay in their home environments comfortably (Sumit et al., 2017). The limitations in the design features of equipment and furniture provided in the elderly houses leads to the situation in which elderly people have to dependent on any support system to perform their activities in the home. For this reason, it is essential to take into consideration the housing needs of the elderly and accommodate the elderly home with ergonomically designed equipment and enable them to lead their life independently, comfortably and age in place Hence the study was aimed to identify the gap between existing home communication system and needs of the elderly.

\section{Materials and Methods}

The study was conducted in the Kurnool district of Andhra Pradesh. Expost-facto research design was followed for the study. Random sampling method was adopted to select the locations to draw the sample. Purposive sampling technique was adopted to draw the sample from the randomly selected study locations. A total of 60 elderly women in the age of sixty and above who were able to carry out their daily chores independently and living in a separate dwelling without children with or without spouse was the criteria for the selection of sample. The standard design guidelines evolved through research by various Government and Nongovernment organizations and researchers served as a yardstick to identify the existing features and needs of elderly people. The data was collected through structured interview cum observation schedule. The socio economic scale "Modified Kuppuswamy scale updated for year 2018" by Saleem (2018) was adopted to study the socioeconomic status of the respondent. The houses of the elderly selected for the present study were physically observed and gathered the information on provisions made in the housing and assessed in terms of scores 3,2 and 1 for 'above the recommended guidelines', 'exactly as per the recommended guidelines' and 'below the recommended guidelines'. The respondents were asked to state their recommendations for provision of home communication system to enable them to live comfortably and independently in old age keeping in view of their limitations. The requirements of the elderly were categorized as 'essential', 'preferred' and 'neutral' with scores 3, 2 and 1 respectively.

Frequencies and percentages were calculated for the existing home communication system and needs of the respondents. Chi square analysis was done to find out the gap between existing home communication system and needs of the respondent.

\section{Standard design guidelines for home communication system}

Guidelines for provision of Home communication systems in the home were gathered through literature survey. Seventeen features that enable the elderly to use the home communication system without any discomfort were identified from the guidelines for home communication system which served as a base for identifying the features to measure the existing communicating systems in the house.

Provision of an automatic fire alarm system, telephone near the bed with large keys, videophone connection in the home and placement of alarm pull cord in the bathroom at a height easily reached by someone lying down were recommended in the elderly housing to ensure safety for elderly people (Welfare housing policies for senior citizens, 2007). Provision of emergency alarm system, automatic remote opening doors, electric fuse boxes with automatic circuit breakers and gas leak detection systems were suggested in 
elderly house (Parker, 1987; Welfare housing policies for senior citizens, 2007, Model guidelines for development and regulation of retirement homes, 2019).

\section{Results and Discussion}

Background information of the
respondents

Most of the elderly women were found educated. Nearly one third of the women born between 1955 and 1965 were found with graduation level of education. Families in their contracting stage of life were found earning neither too high nor too low. Most of them were with sufficient income to live comfortably. The most popular types of houses found were Independent houses, Independent double storied houses, Apartments or flats and Duplex type of houses. The apartment culture was gaining popularity in recent times. The desire to own a house when started life as young couple was fulfilled by majority of the elderly. The houses the elderly residing were not new houses. The elderly might have owned houses and continued their stay in the same houses. Most of the elderly families were found to be in upper middle income category. This generation of families in the contracting stage of family life was found financially, comfortable.

\section{Existing home communication systems in the house of elderly}

Two thirds of the houses were provided with telephone with light indicator $(35 \%)$ that was easily visible and audible within the home. No house was provided with alarm pull cord at bathroom and remotely operated doors in the home. Half of the houses had opening system on the doors which required only one single type of key. Majority (96\%) of the houses were well ventilated in a natural way. More than two thirds of the houses had sound proof waste ducts and pipes to limit annoying noises in the rooms where it was provided. Maximum houses didn't have gas leak detection systems, smoke alarm systems for emergency, burglar proof door, safety and monitoring systems. Ninety-three per cent of the houses had illuminated front door bell. Sixty-eight per cent of the houses had fuse box with automatic circuit breakers. The results were presented in Table 1.

\section{Needs of elderly with reference to home communication system}

Half of the respondents felt essential to provide telephone with large easy to read keys for most used numbers. Thirty-one per cent of the respondents felt essential to have alarm pull cord at bathroom at a height easily reached by someone lying down. More than half $(55 \%)$ of the elderly felt neutral to have opening system on the doors which required only one single type of key. Forty-six per cent of the elderly felt essential to have ventilation for the houses in a natural way. Majority $(81 \%)$ of the respondents felt neutral to have sound proof waste ducts and pipes to limit annoying noises in the rooms. Seventy-eight per cent of the elderly felt essential to have burglar proof doors. More than half $(63 \%)$ of the elderly felt essential to have gas leak detection systems with remote alarms. Majority $(86 \%)$ of the respondents expressed neutral opinion towards the need for emergency alarms, light controls at bed side and also at toilet seat in bathrooms, provision of smoke or file alarm system with remote response facility. The results were presented in Table 2.

\section{Association between existing home communication system and needs of the elderly}

Chi square analysis was done to find out the association between existing home communication system and needs of the 
respondent. The null hypothesis formulated was

$\mathrm{H}_{0}$ There exists no significant association between existing home communication system conditions and needs of elderly with reference to home communication system to age in place

More than half of the respondents (55\%) preferred to have home communication system as per the guidelines. The recommended guidelines for home communication system in the house were provision of various communication systems in various room to assist the elderly in an easy way.
The highly significant Chi-square value revealed a strong evidence against the ull hypothesis. Elderly respondents preferred provision of safety devices. The results of the study are in line with the study conducted by Jaspers (2017) wherein it was found that the provision of emergency alarm systems were preferred by the elderly (Table 3 ).

There exists an association between the existing home communication system and the needs of the respondents to age in place with reference to home communication system.

Hence, null hypothesis was rejected.

Table.1 Distribution of respondents by existing home communication design features

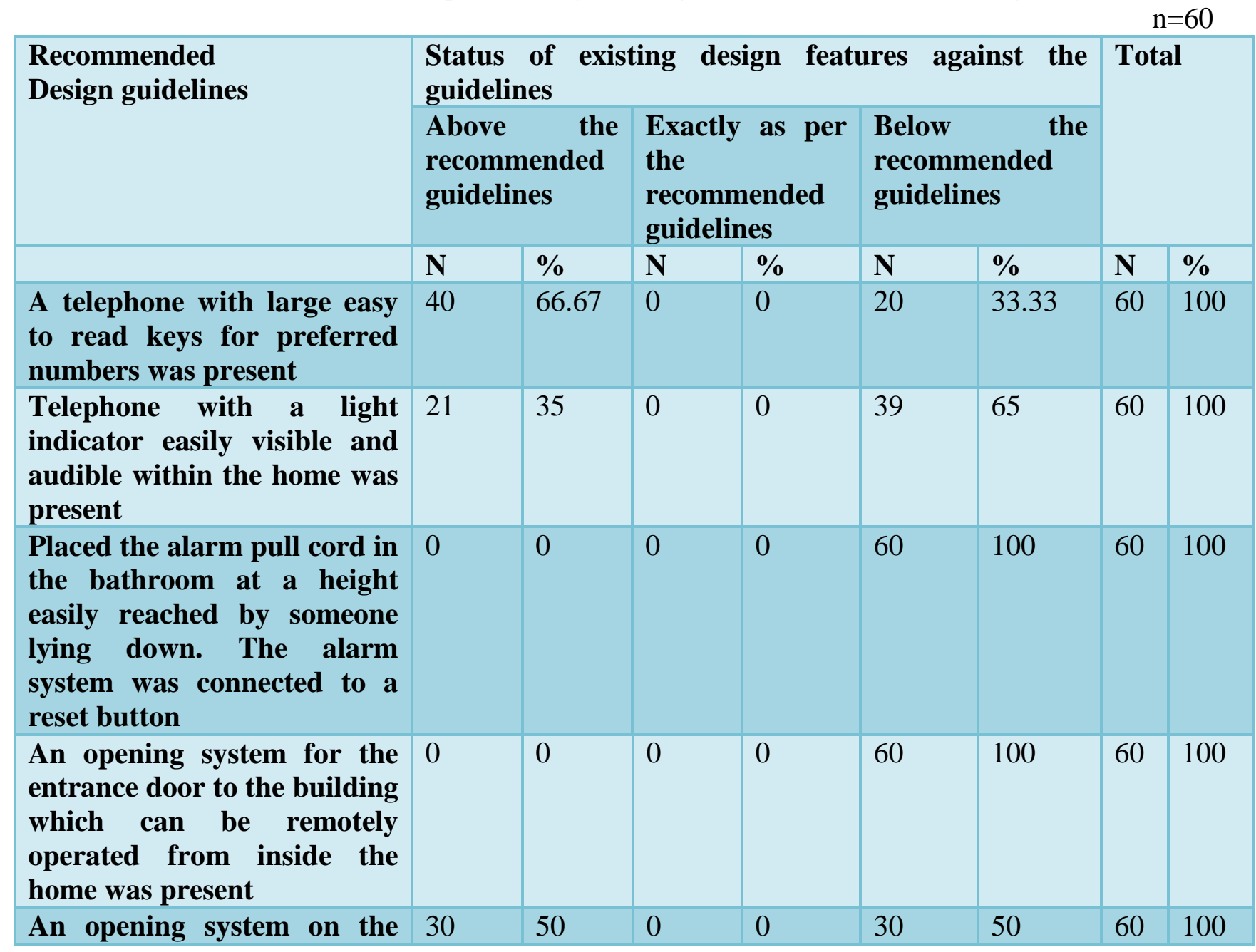




\begin{tabular}{|c|c|c|c|c|c|c|c|c|}
\hline $\begin{array}{l}\text { doors which requires only } \\
\text { one single type of key was } \\
\text { provided }\end{array}$ & & & & & & & & \\
\hline $\begin{array}{l}\text { An automatic or manual } \\
\text { thermostat in the home } \\
\text { which was remotely } \\
\text { regulated was provided }\end{array}$ & 0 & 0 & 0 & 0 & 60 & 100 & 60 & 100 \\
\hline $\begin{array}{l}\text { The home was well } \\
\text { ventilated in a natural way }\end{array}$ & 58 & 96.67 & 0 & 0 & 2 & 3.33 & 60 & 100 \\
\hline $\begin{array}{l}\text { Sound proof waste ducts and } \\
\text { pipes to limit annoying } \\
\text { noises in the bedroom and } \\
\text { living room were provided }\end{array}$ & 41 & 68.33 & 0 & 0 & 19 & 31.67 & 60 & 100 \\
\hline $\begin{array}{l}\text { For homes on the ground } \\
\text { floor safety systems on all } \\
\text { external doors and windows } \\
\text { were installed }\end{array}$ & 1 & 1.67 & 0 & 0 & 59 & 98.33 & 60 & 100 \\
\hline $\begin{array}{l}\text { For homes on higher floors } \\
\text { safety systems (or alarms) on } \\
\text { windows and any balcony } \\
\text { doors were installed }\end{array}$ & 0 & 0 & 0 & 0 & 60 & 100 & 60 & 100 \\
\hline $\begin{array}{l}\text { A video system for tele } \\
\text { assistance or a personal } \\
\text { alarm system which allows } \\
\text { for remote warning was } \\
\text { provided }\end{array}$ & 0 & 0 & 0 & 0 & 60 & 100 & 60 & 100 \\
\hline $\begin{array}{l}\text { Provided an illuminated } \\
\text { front door bell }\end{array}$ & 56 & 93.33 & 0 & 0 & 4 & 6.67 & 60 & 100 \\
\hline $\begin{array}{l}\text { Burglar proof front doors } \\
\text { were provided }\end{array}$ & 0 & 0 & 0 & 0 & 60 & 100 & 60 & 100 \\
\hline $\begin{array}{l}\text { Fuse boxes had automatic } \\
\text { circuit breakers }\end{array}$ & 41 & 68.33 & 0 & 0 & 19 & 31.67 & 60 & 100 \\
\hline $\begin{array}{l}\text { Gas leak detection systems } \\
\text { with remote alarms were } \\
\text { provided }\end{array}$ & 0 & 0 & 0 & 0 & 60 & 100 & 60 & 100 \\
\hline $\begin{array}{l}\text { Installed smoke/fire alarm } \\
\text { systems which also had } \\
\text { remote response facility }\end{array}$ & 0 & 0 & 0 & 0 & 60 & 100 & 60 & 100 \\
\hline $\begin{array}{l}\text { Emergency alarms and light } \\
\text { controls at bedside and } \\
\text { bathrooms near toilet seat } \\
\text { were provided }\end{array}$ & 0 & 0 & 0 & 0 & 60 & 100 & 60 & 100 \\
\hline
\end{tabular}


Table.2 Distribution of respondents by their needs in designing a home communication system

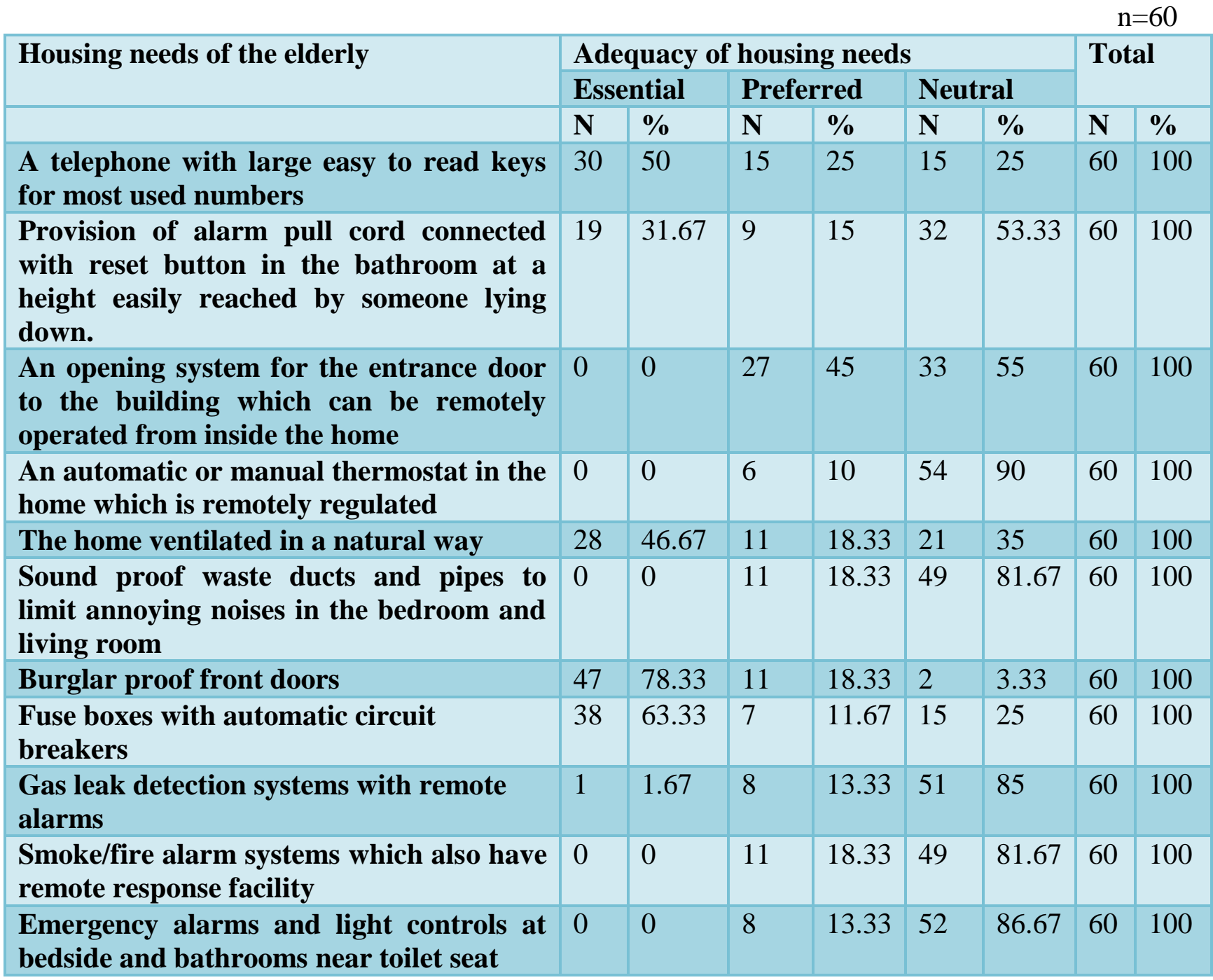

Table.3 Association between existing home communication system and needs of the elderly

$\mathrm{n}=60$

\begin{tabular}{|c|c|c|c|c|c|c|}
\hline \multirow[t]{3}{*}{$\begin{array}{c}\text { Existing home communication } \\
\text { system }\end{array}$} & \multicolumn{6}{|c|}{$\begin{array}{l}\text { Design needs with reference to } \\
\text { home communication system }\end{array}$} \\
\hline & \multicolumn{2}{|c|}{ Neutral } & \multicolumn{2}{|c|}{ Preferred } & \multicolumn{2}{|c|}{ Total } \\
\hline & $\mathrm{N}$ & $\%$ & $\mathrm{~N}$ & $\%$ & $\mathrm{~N}$ & $\%$ \\
\hline Below the recommended guidelines & 14 & 23.33 & 13 & 21.67 & 27 & 45.00 \\
\hline $\begin{array}{l}\text { Exactly as per the recommended } \\
\text { guidelines }\end{array}$ & 1 & 1.67 & 32 & 53.33 & 33 & 55.00 \\
\hline Total & 15 & 25.00 & 45 & 75.00 & 60 & 100.00 \\
\hline$\square^{2}$ value & \multicolumn{6}{|c|}{18.8777} \\
\hline Probability value & \multicolumn{6}{|c|}{$<.0001 *$} \\
\hline
\end{tabular}

Note- *- significant at 1 per cent level 
In conclusion, advanced home communication design features such as alarm pull cord in the bathroom at a height easily reached by someone lying down, an opening system for the entrance door to the building which can be remotely operated from inside the home, an automatic or manual thermostat which can be remotely regulated, gas leak detection systems with remote alarms, smoke/fire alarm systems, emergency alarms and light controls at bedside and bathrooms near toilet seat were not found in all most all of the houses.

Telephone with large easy to read keys, an opening system on the doors which requires only one single type of key, sound proof waste ducts and pipes to limit annoying noises were some of the design features provided in existing houses. Advanced communication devices were not popular among existing houses.

The elderly felt essential to provide a telephone with large easy to read keys for preferred numbers, an opening system on the doors which requires only one single type of key, sound proof waste ducts and pipes to limit annoying noises, burglar proof front doors, fuse boxes with automatic circuit breakers.

\section{References}

Bostjan, K.2018.Using Information and Communication Technology in Home
Care for the Elderly. In: Mukadder Mollaoglu (ed.), Caregiving and Home Care. Intech Open Limited, London, UK.pp.205.

Jaspers, M.J.J.E. 2017. Housing Preferences of an Ageing Population. M.Sc. Thesis. Eindhoven University of Technology, Netherlands.

Model Guidelines for Development and Regulations of Retirement homes. 2019. Ministry of Housing and Urban Affairs, Government of India. http://mohua.gov.in/upload/uploadfiles/f iles/Retirement\%20Model\%20Guidelin es\%20Book.pdf

Parker, W.R. 1987. Housing for the elderly. In: J. DeChaira and J. Callender (eds.) Time Saver Standards for Building Types, $\quad 2^{\text {nd }} \quad$ ed. McGraw-hill International Editions. pp. 87-101.

Saleem, S.M. 2018. Modified Kuppuswamy scale updated for year 2018. ParipexIndian Journal of Research. 7(3):435436.

Welfare housing policies for senior citizens. 2007. Guidelines for the planning of houses for senior citizens.https://www.housinglin.org.uk/ _assets/Resources/Housing/Support_ma terials/Other_reports_and_guidance/

Sumit, M., Emad, A., Moein, N., Hamidreza, M., Tapas, M., Zhibo, P and Jamal D, M.2017.Smart Homes for Elderly Healthcare-Recent Advances and Research Challenges. Sensors. 17(11): 2496.

\section{How to cite this article:}

Unesha Fareq, R. and Neeraja, T. 2020. Smart Home for Elderly: Exploring Gap between Existing Home Communication System and Needs of Elderly. Int.J.Curr.Microbiol.App.Sci. 9(08): 2152-2158. doi: https://doi.org/10.20546/ijcmas.2020.908.245 